\title{
Mystery Case: White matter lesion related to decompression sickness following extreme breath-hold diving
}

Carla Guerreiro, MD, Andreia Teixeira, MD, Tiago Marques, MD, and Sofia Reimão, MD, PhD

Neurology ${ }^{\circledR}$ 2018;91:847-848. doi:10.1212/WNL.0000000000006441
Correspondence

Dr. Guerreiro

cleaoguerreiro@gmail.com

Figure Axial brain MRI
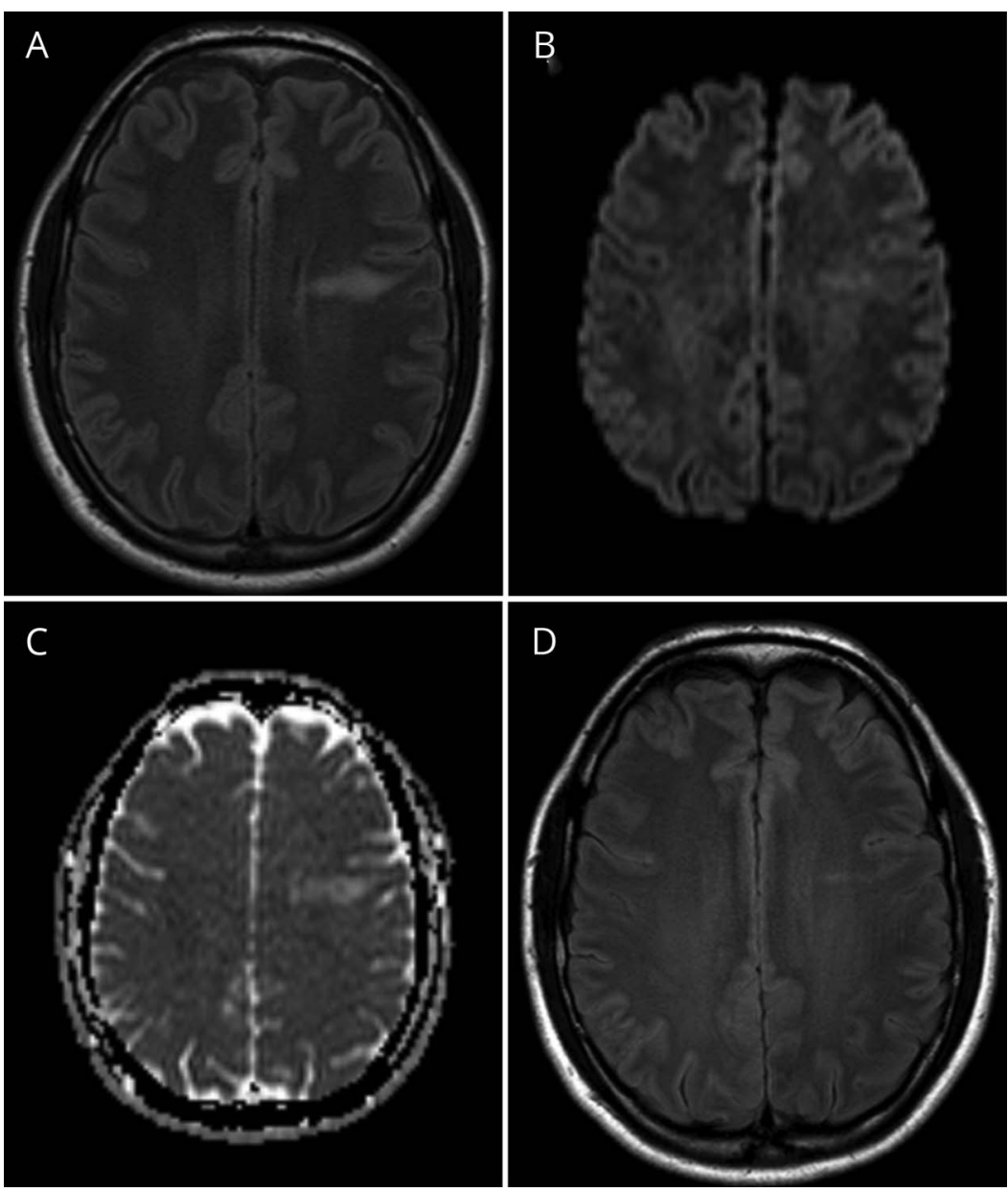

(A) Initial FLAIR shows a hyperintense subcortical linear left frontal lesion, sparing the subcortical U-fibers. On diffusion-weighted imaging (B), the lesion is hyperintense, without corresponding low apparent diffusion coefficient map values (C), showing no restricted diffusion. (D) FLAIR at 1-month follow-up shows subtotal lesion regression.

A 39-year-old man developed transient expressive aphasia and headache following extreme breath-hold diving. He had performed around 30 breath-hold dives, lasting approximately 2 minutes, 30 meters deep, for 5 hours, with short surface intervals. Brain MRI (figure, A-C) revealed a left frontal white matter lesion, without restricted diffusion, contrast enhancement, or mass effect.

From the Neuroimaging Department (C.G., S.R.) and the Infectious Diseases Department (T.M.), North Lisbon Hospital Center; and Underwater and Hyperbaric Medicine Center (A.T.), Portuguese Navy, Portugal.

Go to Neurology.org/N for full disclosures. Funding information and disclosures deemed relevant by the authors, if any, are provided at the end of the article. 
At 1-month follow-up, after 3 treatment sessions of hyperbaric oxygen therapy, the patient remained asymptomatic and the lesion had regressed almost completely (figure, D).

Accumulation of nitrogen in blood and tissues after repetitive breath-hold diving ${ }^{1}$ has been suggested to cause endothelial dysfunction and disruption of the blood-brain barrier, with subsequent hyperpermeability in microvasculature and vasogenic edema. ${ }^{2}$

\section{Author contributions}

C. Guerreiro: acquisition of data and manuscript elaboration. A. Teixeira: acquisition of data and manuscript elaboration. T. Marques: manuscript revision. Sofia Reimão: supervision and critical revision.

\section{Study funding}

No targeted funding reported.

\section{Disclosure}

The authors report no disclosures relevant to the manuscript. Go to Neurology.org/N for full disclosures.

\section{References}

1. Kohshi K, Tamaki H, Lemaître F, Okudera T, Ishitake T, Denoble PJ. Brain damage in commercial breath-hold divers. PLoS ONE 2014;9:e105006.

2. Matsuo R, Kamouchi M, Arakawa S, Furuta Y, Kanazawa Y, Kitazono T. Magnetic resonance imaging in breath-hold divers with cerebral decompression sickness. Case Rep Neurol 2014;6:23-27.

\section{Mystery Case Responses: A 39-year-old man with transient aphasia}

The Mystery Case series was initiated by the Neurology ${ }^{\circledR}$ Resident \& Fellow Section to develop the clinical reasoning skills of trainees. Residency programs, medical student preceptors, and individuals were invited to use this Mystery Case as an educational tool. Responses to multiple choice questions formulated using this case were solicited through a group email sent to the American Academy of Neurology Consortium of Neurology Residents and Fellows and through social media. We received 161 responses. The majority of respondents (70\%) had been in practice for $1-4$ years; $65 \%$ were residents or fellows while $29 \%$ were faculty/board-certified physicians; the remainder were medical students or advanced practice providers. A total of $48 \%$ resided outside the United States. A wide range of practice settings was represented.

When presented with this patient's history of transient expressive aphasia and headache following extreme breath-hold diving, and shown the initial MRI brain, 63\% of respondents correctly recognized the findings of hyperintense left frontal fluid-attenuated inversion recovery (FLAIR) lesion (sparing subcortical U-fibers), and 33\% also recognized the FLAIR/ diffusion-weighted imaging (DWI)/apparent diffusion coefficient $(A D C)$ findings as being suggestive of vasogenic edema. When asked what treatments they would consider, $73 \%$ correctly selected hyperbaric oxygen therapy and $40 \%$ selected initial high flow oxygen. A total of $18 \%$ incorrectly selected aspirin, which is not indicated in this case as the patient did not actually have a stroke/TIA.

Upon then being provided the patient's follow-up MRI showing regression of the lesion after 3 treatment sessions of hyperbaric oxygen therapy, and asked to identify potential mechanisms for this presentation, the following appropriate mechanisms were identified: (1) accumulation of nitrogen in blood and tissues after repetitive breath-hold deep-diving (by 44\%), (2) endothelial dysfunction and disruption of the blood-brain barrier (by 18\%), (3) bubble formation in the vasculature from excess dissolved gases (45\%), and (4) hyperpermeability in brain microvasculature contributing to vasogenic edema (24\%). One favored incorrect option was vaso-occlusion due to the dissolving of nitrogen in blood under high pressure (33\%). Small nitrogen emboli are an important complication of deep sea and scuba diving, resulting in Caisson disease, with ischemia of the brain and spinal cord and prominent signs of spinal cord dysfunction; hyperbaric oxygen is the usual treatment. ${ }^{1}$ However, such occlusive emboli are unlikely to have occurred in this case given the absence of true diffusion restriction (bright on DWI, dark on ADC) as expected with ischemia on neuroimaging.

This case highlights a complication of decompression sickness following extreme breath-hold diving that may present to neurologists.

Steve O'Donnell, MD

Vascular Neurology Fellow, University of Washington, Seattle

Aravind Ganesh, MD

Department of Clinical Neurosciences, University of Calgary, Alberta, Canada; Centre for Prevention of Stroke and Dementia, University of Oxford, UK

\section{Reference}

1. Biller J, Ruland S, Schneck MJ. Ischemic cerebrovascular disease. In: Daroff RB, Jankovic J, Mazziotta JC, Pomeroy SL, eds. Bradley's Neurology in Clinical Practice, 7th ed, vol 1. London: Elsevier; 2016:945. 


\section{Neurology}

\section{Mystery Case: White matter lesion related to decompression sickness following extreme breath-hold diving}

Carla Guerreiro, Andreia Teixeira, Tiago Marques, et al.

Neurology 2018;91;847-848

DOI 10.1212/WNL.0000000000006441

This information is current as of October 29, 2018

\section{Updated Information \& Services}

References

Subspecialty Collections

Permissions \& Licensing

Reprints including high resolution figures, can be found at: http://n.neurology.org/content/91/18/847.full

This article cites 3 articles, 0 of which you can access for free at: http://n.neurology.org/content/91/18/847.full\#ref-list-1

This article, along with others on similar topics, appears in the following collection(s):

All Cerebrovascular disease/Stroke

http://n.neurology.org/cgi/collection/all_cerebrovascular_disease_strok

\section{All Education}

http://n.neurology.org/cgi/collection/all_education

MRI

http://n.neurology.org/cgi/collection/mri

Other cerebrovascular disease/ Stroke

http://n.neurology.org/cgi/collection/other_cerebrovascular_disease_st roke

Information about reproducing this article in parts (figures,tables) or in its entirety can be found online at:

http://www.neurology.org/about/about_the_journal\#permissions

Information about ordering reprints can be found online:

http://n.neurology.org/subscribers/advertise

Neurology ${ }^{\circledR}$ is the official journal of the American Academy of Neurology. Published continuously since 1951, it is now a weekly with 48 issues per year. Copyright (O) 2018 American Academy of Neurology. All rights reserved. Print ISSN: 0028-3878. Online ISSN: 1526-632X.

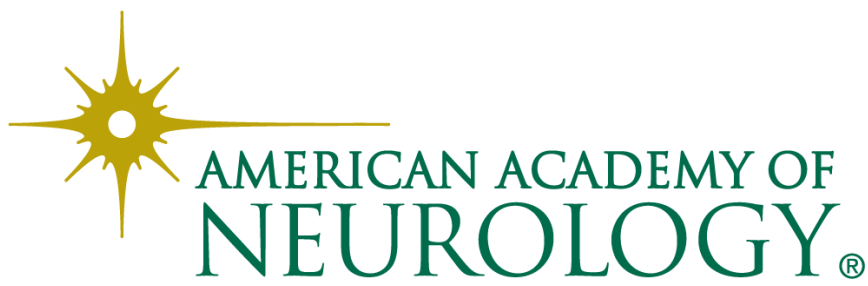

